\title{
Financial literacy as knowledge necessary in today's globalized world
}

\author{
Markéta Beranová ${ }^{1, *}$, Jan Š́ma ${ }^{2}$, and Miroslava Navrátilová ${ }^{1}$ \\ ${ }^{1}$ Czech University of Life Sciences in Prague, Kamýcká 129, Prague, 165 21, Czech Republic \\ ${ }^{2}$ Charles University, José Martího 269/31, Prague, 162 52, Czech Republic
}

\begin{abstract}
The current globalized world requires individuals to take responsibility for their decisions. Therefore, it is necessary that the younger generation reach a certain level of knowledge, including knowledge of financial literacy. Financial literacy covers an important area - security in old age. The aim of this paper is to assess the level of financial literacy amongst university students, with a focus on income security in old age. Primary data were obtained by quantitative research using a questionnaire survey ( $n=1437)$ in 2018 amongst full-time bachelors and masters degree students at three universities. The selected universities focus on economy and agriculture and each of them is located in a different region of the Czech Republic. The results show that $47.8 \%$ of respondents worry about their income security in old age. As a way of financing the retirement, most of the respondents chose the option "from the state pension and in another way". Statistical evaluation proved dependence between the gender of respondents and the responses mentioned above. Women more often chose the "from state pension and in another way" option than men. On the other hand, men chose the "in another way" option more often. It follows that men do not want to be dependent on the state, but they want to secure themselves in another way.
\end{abstract}

\section{Introduction}

Financial literacy has become a skill required for life and prosperity in the contemporary economy [1].

The level of financial literacy affects individuals and, by doing so, shapes the image of the society as a whole. The impact of the level of financial literacy on households is obvious as it has implications on the households' economy, their decision-making, and planning [2, 3].

The challenges of financial decision-making now faced by the younger generation are far more difficult to cope with that those faced by the previous generations. Thanks to globalization and digital technologies, financial services and products, for example, have become more complex on the one hand, but more accessible on the other. Individuals must take more responsibility for their financial decisions like investment in higher education, saving for education of their children, and planning for their retirement $[4,5]$.

\footnotetext{
*Corresponding author: mberanova@pef.czu.cz
} 
It is vital to enhance the level of financial literacy, mainly in young adults where the potential to positively impact their financial attitudes and behaviours is significant and benefits both individuals and the entire globalized economy [6-8].

The objective of this paper is to assess, based on primary research performed at the selected universities in the Czech Republic, the level of financial literacy of full-time bachelor's and master's degree students in relation to income security in old age.

The theoretical framework is presented in the Introduction. The Methods and Materials chapter deals with the method of performing the primary research and the description of the surveyed sample of respondents in terms of basic sociodemographic characteristics. The Results and Discussion chapter presents the results of the survey and includes a discussion and a comparison of the outcomes of our research with similar surveys in terms of the investigated issues. The most important findings are shown in the Conclusion chapter.

\section{Methods and Materials}

The theoretical background of this paper is based on the analysis of secondary sources encompassing scholarly papers and reference literature. Primary data have been obtained from our own survey.

Conducted with the help of paper questionnaires, the research was carried out among regular full-time bachelor's and master's degree students at three universities in the Czech Republic in 2018. The selection of the sample set was purposive and 1,437 respondents took part in the questionnaire survey of financial literacy. The questions dealt with in this paper relate to income security in old age.

Table 1. Basic characteristics of respondents in \%

\begin{tabular}{|c|c|c|c|}
\hline \multirow{2}{*}{ Gender } & Male & 42.52 & \multirow{2}{*}{100} \\
\hline & Female & 57.48 & \\
\hline \multirow{3}{*}{ University } & $\begin{array}{l}\text { Jihočeská univerzita, } \\
\text { České Budějovice }\end{array}$ & 18.02 & \multirow{3}{*}{100} \\
\hline & $\begin{array}{l}\text { Česká zemědělská } \\
\text { univerzita v Praze }\end{array}$ & 59.29 & \\
\hline & $\begin{array}{c}\text { Mendelova } \\
\text { univerzita, Brno } \\
\end{array}$ & 22.69 & \\
\hline \multirow{2}{*}{ Level of study } & Bachelor's degree & 66.32 & \multirow{2}{*}{100} \\
\hline & Master's degree & 33.68 & \\
\hline \multirow{2}{*}{ Field of study } & Economic studies & 63.40 & \multirow{2}{*}{100} \\
\hline & Noneconomic studies & 36.60 & \\
\hline
\end{tabular}

The contingency table is used to transparently visualize the mutual relations of the two statistical variables. The type of the contingency table is determined by the number of rows $\mathrm{r}$ and the number of columns s, it means $r \times s$ [9]. Obviously, $\chi^{2}$ is a measure of the overall dissimilarity of $n_{i j}$ and $m_{i j}$. The bigger the difference between the observed and the expected values, the higher the test statistics. 


$$
\begin{gathered}
m_{i j}=\frac{n_{i} \cdot n_{j}}{n} \\
\chi^{2}=\sum \frac{(\text { frequency observed }- \text { frequency expected })^{2}}{\text { frequency expected }} \\
\chi^{2}=\sum_{i=1}^{r} \sum_{j=1}^{s}\left(n_{i j}-m_{i j}\right)^{2} / m_{i j}
\end{gathered}
$$

$i$ and $j$ are indices of rows and columns, $n_{i j}$ are the marginal frequencies observed, $n_{i}$ and $n_{j}$ are marginal totals, $n$ is grand total of observations, $m_{i j}$ are the expected frequencies. We compare the critical value with a chi-square distribution of $(r-1)(s-1)$ degrees of freedom at the chosen level of significance. We reject the hypothesis that the critical value is larger than the table value. This test is valid asymptotically and, thus, can only be applied if there is a sufficient number of observations. All expected values ought to be higher than one [10]; at the same time, the table should not contain more than $20 \%$ of theoretical incidence rates (frequencies) lower than 5 . Where zero values occur in any of the fields, we proceed to analyse a derived table created by merging a small number of categories [10]. Cramér's $V$ was used to determine the degree of association between the variables.

Table 2. Wording of the tested null hypotheses

\begin{tabular}{|c|c|}
\hline Hypothesis No. & Wording of Hypothesis \\
\hline $\mathrm{H}_{1}$ & $\begin{array}{c}\text { Respondent's thinking about their income } \\
\text { security in old age is independent of gender. }\end{array}$ \\
\hline $\mathrm{H}_{2}$ & $\begin{array}{c}\text { Respondent's thinking about their income } \\
\text { security in old age is independent of the } \\
\text { university. }\end{array}$ \\
\hline $\mathrm{H} 0_{3}$ & $\begin{array}{c}\text { Respondent's thinking about their income } \\
\text { security in old age is independent of the } \\
\text { scientific focus of the faculty. }\end{array}$ \\
\hline $\mathrm{H}_{4}$ & $\begin{array}{c}\text { Respondent's thinking about their income } \\
\text { security in old age is independent of the } \\
\text { degree of their study. }\end{array}$ \\
\hline $\mathrm{H}_{5}$ & $\begin{array}{c}\text { The way of funding the needs in old age is } \\
\text { independent of gender. }\end{array}$ \\
\hline $\mathrm{H}_{6}$ & $\begin{array}{c}\text { The way of funding the needs in old age is } \\
\text { independent of the university. }\end{array}$ \\
\hline $\mathrm{H} 0_{7}$ & $\begin{array}{c}\text { The way of funding the needs in old age is } \\
\text { independent of the scientific focus of the } \\
\text { faculty. }\end{array}$ \\
\hline $\mathrm{H} 0_{8}$ & $\begin{array}{c}\text { The way of funding the needs in old age is } \\
\text { independent of the degree of the study. }\end{array}$ \\
\hline
\end{tabular}

\section{Results and Discussion}

First, all respondents were asked if they had been thinking about their income security in old age. All respondents answered this question, of which $24.63 \%$ (354) said that they had already been thinking about this issue - answer "yes". 23.17\% (333) of respondents answered "rather yes". "rather no" was the most frequent answer given by $34.17 \%$ (491) of persons. 
$17.61 \%$ (253) of respondents answered "no" and this means that they have not considered this issue yet. A negligible number of respondents answered "don't know" - they were only very few (6 persons representing $0.42 \%$ of respondents) and, therefore, this answer was integrated with the answer "no".

Four null hypotheses were tested in relation to this question.

Table 3. Calculation of variables for the tested hypotheses $\mathrm{H}_{1}-\mathrm{H} 0_{4}$

\begin{tabular}{|c|c|c|c|c|}
\hline $\begin{array}{c}\text { Hypothesis } \\
\text { No. }\end{array}$ & $\chi \mathbf{2}$ & Critical value & $\begin{array}{c}\text { H0 can be } \\
\text { discarded }\end{array}$ & Cramér's V \\
\hline $\mathrm{H}_{1}$ & 9.57 & 7.81 & $X$ & 0.11 \\
\hline $\mathrm{H}_{2}$ & 12.37 & 12.59 & - & - \\
\hline $\mathrm{H}_{3}$ & 3.74 & 7.81 & - & - \\
\hline $\mathrm{H}_{4}$ & 2.55 & 7.81 & - & - \\
\hline
\end{tabular}

Table 3 shows that only dependence on one of the investigated variables - respondents' gender - has been proved.

The value of statistic $\chi^{2}$ for $\mathrm{H}_{1}$ is higher than the critical value on the level of significance equal to 0.05 . The null hypothesis can be rejected. Thus, the dependence between the student's considering their income security in old age and their gender has been proved. The value of Cramér's V totals 0.11 and the measure of association can, therefore, be considered as low. The difference between empirical and theoretical distributions on the level of significance equalling 0.05 proved true for answer "yes" as this option was statistically significantly more often chosen by men $(27.98 \%, 171)$ than by women $(22.16 \%, 183)$.

In relation to the above, the question about the way of funding the needs at retirement age was asked. "From the state pension and in another way (from insurance, etc.)" was the most frequently chosen option, this response was received from 76.13\% (1 094) of respondents. "In another way" was the second most frequent answer given by $14.89 \%$ (214) of respondents. Respondents were encouraged to provide more details on this and the most frequently given specifications of another income were: income from real property or other assets (equities), fixed income, and there was also an answer referring to support from parents. Only $8.98 \%$ (129) - the lowest number of respondents - said that they planned to cover their needs at retirement age only "from pension provided by the state". Four hypotheses were tested in relation to this question.

Table 4. Calculation of variables for the tested hypotheses $\mathrm{H}_{5}-\mathrm{H}_{8}$

\begin{tabular}{|c|c|c|c|c|}
\hline Hypothesis No. & $\chi \mathbf{2}$ & Critical value & $\begin{array}{c}\text { Ho can be } \\
\text { discarded }\end{array}$ & Cramér's V \\
\hline $\mathrm{H}_{5}$ & 43.45 & 5.99 & $\mathrm{X}$ & 0.17 \\
\hline $\mathrm{H} 0_{6}$ & 72.68 & 9.49 & $\mathrm{X}$ & 0.16 \\
\hline $\mathrm{H} 0_{7}$ & 6.33 & 5.99 & $\mathrm{X}$ & 0.07 \\
\hline $\mathrm{H} 0_{8}$ & 0.46 & 5.99 & - & - \\
\hline
\end{tabular}

Table 4 summarizes outcomes of the tested hypotheses and shows that there is dependence on gender, university, and scientific focus of the faculty in terms of funding the needs in old age. 
The value of statistic $\chi^{2}$ for $\mathrm{H}_{5}$ is higher than the critical value on the level of significance equal to 0.05 . The null hypothesis can be rejected. Thus, the dependence between the planned way of covering the respondents' needs in old age and their gender has been proved. The value of Cramér's V totals 0.17 and the measure of association can, therefore, be considered as low. Statistically significant difference on level 0.001 is shown in "from the state pension and in another way" as this answer was chosen more often by women $(79.90 \%, 660)$, and also in in another way" as this option was chosen significantly more often by men $(21.93 \%$, 134). It can be concluded from the responses received that men do not want to be dependent on pension after reaching retirement age and tend to think more about how to assure their income security.

The value of statistic $\chi^{2}$ for $\mathrm{H}_{6}$ is higher than the critical value on the level of significance equal to 0.05 . The null hypothesis can be rejected. Thus, the dependence between the planned way of covering the respondents' needs in old age and their university has been proved. The value of Cramér's V totals 0.16 and the measure of association can, therefore, be considered as low. Statistically significant difference on level 0.001 was identified and it is shown in "from pension provided by the state" as this answer was chosen more often by respondents from JČU $(22.01 \%, 57)$ who preferred this option to "from the state pension and in another way". By contrast, students at ČZU chose "from pension provided by the state" significantly less often $(4.81 \%, 41)$ and, compared to theoretical distributions and statistically significantly on level 0.01 , preferred "from the state pension and in another way" $(78.99 \%, 673)$.

After comparing the value of statistic $\chi^{2}$ for $\mathrm{H}_{7}$, which is slightly higher than the critical value on the level of significance equal to 0.05 , the null hypothesis can be rejected. Thus, the dependence between the way of covering the respondents' needs in old age and the scientific focus of their faculty has been proved. The value of Cramér's V totals 0.07 and the measure of association is, therefore, very low. Moreover, it was found that there were differences mainly in the "in another way" option on the level of significance equal to 0.05 as this response was chosen more often by students at the faculty of economic studies $(16.47 \%$, 150 ), which can be interpreted as a conviction of students of economic studies that they will be able to achieve their income security in another way than students of non-economic studies $(12.16 \%, 64)$.

It can be concluded from the outcomes of the surveys already conducted that a higher level of financial literacy is significantly and positively correlated to plans regarding retirement, mainly in terms of considering financial resources necessary to achieve income security in old age [11]. This statement is also supported by other author who emphasize that knowledge in the domain of financial literacy is interrelated with economic behaviours, including decision-making and planning of retirement and income security in old age [12]. Also, this is confirmed by other author [13] who states that pressure on individuals in terms of assuming responsibility for their income security at retirement age is gradually growing. Financial education of all age groups is one of the tools available to enhance the ability to take informed decisions regarding the future income security in old age and to help members of each group to take responsibility for their and their family's income security [14]. The age structure suggests that the growing instability and sustainability of the public pension system are burning issues of the present and the near future [15].

\section{Conclusion}

The outcomes of the questionnaire survey suggest that income security is an issue that may have a significant impact on economy. Of the total number of respondents $(1,437)$, only $47.80 \%$ (687) responded that they had already thought about their income security in old age and that they took it into consideration. More than half of respondents $(52.20 \%, 744)$ answered that they did not take this issue into consideration. 
In view of the said outcomes, it is vital to inform university students of the issue of income security in old age. It is these young people who will have to deal with the necessity to find alternative ways of funding their needs in old age. The respondents said they were aware of the need to have another source of finance to cover their needs, but only very few of them had already used such a source.

Highlighting the issue of financial literacy among young people in relation to their income security in old age can be considered as the theoretical contribution of the paper, while the presentation of the outcomes of the survey on financial literacy among students at three selected universities in the Czech Republic represents its practical aspect.

This paper is a partial result of the research project No. 2019B0010 - Czech Social System Fraud Rate Estimation and System Optimization Proposals, supported by the Internal Grant Agency (IGA) of Faculty of Economics and Management, CULS Prague.

\section{References}

1. A. Lusardi, Financial literacy skills for the 21st century: evidence from PISA. Journal of Consumer Affairs 49, 639-659 (2015)

2. X. Feng, B. Lu, X. Song, S. Ma, Financial literacy and household finances: A Bayesian two-part latent variable modeling approach. Journal of Empirical Finance 51, 119-137 (2019)

3. W. Bosshardt, W. Walstad, Does studying economics in college influence loan decisions later in life? The Journal of Economic Education 49, 130-141 (2018)

4. M. Beranová, M. Navrátilová, J. Šišková, M. Stárová, Financial literacy of university students in relation to financial security in old age. Proceedings of the 14th International Conference Efficiency and Responsibility in Education (ERIE). Prague: Czech University of Life Sciences Prague, 25-32 (2017)

5. B. Gavurová, E. Huculova, M. Kubák, M. Cepel, The state of students' financial literacy in selected slovak universities and its relationship with active pension savings. Economics and Sociology 10, 206-219 (2017)

6. S. A. Cole, A. L. Paulson, G. K. Shastry, Smart Money: The effect of education on financial behavior, (2012)

7. K. Ševčík, Finanční gramotnost v projektovaném kurikulu Austrálie. Scientia in educatione 8, 46-64 (2017)

8. S. Shahrabani, Financial literacy among israeli college students. Journal of College Student Development 54, 439-446 (2013)

9. R. Hindls, S. Hronová, J. Seger, J. Fischer, Statistika pro ekonomy (Praha: Professional publishing, 2007)

10. J. Hendl, Přehled statistických metod: analýza a metaanalýza dat (Praha: Portál, 2009)

11. H. M. Prast, A. Van Soest, Financial literacy and preparation for retirement. Intereconomics 51, 113-118 (2016)

12. T. Bucher-Koenen, A. Lusardi, R. Alessie, M. Van Rooij, How financially literate are women? An overview and new insights. Journal of Consumer Affairs 51, 255-283 (2016)

13. L. Vidovičová, Financial literacy in retirement planning context: The case of Czech older workers (New York: Springer, 2012)

14. M. Kazda, V. Petrášková, P. Rosa, Effective methods of teaching financial issues. Proceedings of the 13th International Conference Efficiency and Responsibility in Education (ERIE). Prague: Czech University of Life Sciences Prague, 271-278 (2016) 
15. L. Rey-Ares, S. Fernández-López, M. Vivel-Búa, The influence of social models on retirement savings: evidence for european countries. Social Indicators Research 136, 247-268 (2018) 